\title{
Isotopic Insights into Dietary Life History, Social Status, and Food Sharing in American Samoa
}

\author{
Jelmer W. Eerkens, Eric J. Bartelink, Julianna Bartel, and Phillip R. Johnson
}

\begin{abstract}
We test the antiquity of a dietary life history model on Tutuila, American Samoa. Stable carbon and nitrogen isotopes in serial, age-adjusted samples of first and third molars reveal isotopic biographies of 16 individuals from five late Holocene (200-1100 RCYBP) sites. Combining this with bone collagen from a larger sample of individuals, we document a patterned dietary life history on the island. Between ages zero and two years, infants show elevated $\delta^{15} N$ values, consistent with a diet rich in breast milk. In early childhood (two-10 years), individuals shift to a diet with higher $\delta^{13} C$ values, suggesting greater marine protein intake. Around age 10 years, males shift to a more terrestrially focused diet, while females retain a higher marine signature. After 20 years of age, males and females are more similar in diet, with a greater contribution from terrestrial resources. We argue that these shifts reflect diet-marked social transitions in life histories, especially social status and eating order within households, as predicted from the ethnographic model. When contextualized with other archaeological data, such as mortuary patterns and social organization, the isotopic biographic approach facilitates examination of diet-linked social transitions of individuals as they aged within ancient societies.
\end{abstract}

Keywords: American Samoa, Tutuila, Late Holocene, stable isotopes, food sharing, households, isobiography, weaning

En este artículo ponemos a prueba la antigüedad de un modelo etnográfico sobre la historia de vida dietética y la organización de las unidades domésticas en la Isla de Tutuila, localizada en la Samoa Americana. Analizamos los isótopos estables de carbono y nitrógeno en muestras seriadas ajustadas a la edad del primer y tercer molar. Estas representan las biografías isotópicas de 16 individuos procedentes de 5 sitios arqueológicos del Holoceno tardío (200-1100 aP). Combinando esta información con muestras adicionales de colágeno óseo, extraídas de un mayor número de individuos, pudimos documentar el patrón dietético de individuos en la isla. La mayoría de los infantes entre 0 y 2 años de edad muestra niveles elevados de $\delta^{15} \mathrm{~N}$, en consonancia con una dieta rica en leche materna. En la niñez temprana (2-10 años) hay un cambio hacia niveles más elevados de $\delta^{13} \mathrm{C}$, lo que sugiere un consumo mayor de proteínas marinas. Alrededor de los 10 años de edad, los individuos de sexo masculino cambian a una dieta basada en recursos terrestres, mientras que aquellos de sexo femenino retienen valores elevados de $\delta^{13} \mathrm{C}$ asociados con el consumo de proteínas marinas. Después de aproximadamente 20 años de edad, ambos sexos muestran más similitud en el patrón dietético. Argumentamos que los cambios reflejan las transiciones sociales en las historias de vida de los individuos. Cuando se contextualiza con otros datos arqueológicos, como patrones funerarios y organización social, el enfoque biográfico isotópico facilita el examen de las transiciones sociales ligadas a la dieta a lo largo de la vida de los individuos en sociedades antiguas.

Palabras clave: Samoa Estadounidense, Isla de Tutuila, Holoceno tardío, isótopos estables, aprovechamiento compartido de alimentos, grupos domésticos, isobiografía, destete

$\mathrm{T}$ The human life course is marked by a number of important events and transitions. Some of these are biologically based, involving notable changes to the human body, such as teething, sexual maturation, and menopause. However, many transitions are simultaneously, or exclusively, marked by cultural and ritual events, such as weddings, feasts, or other social gatherings to celebrate and advertise such transitions. While the biological transitions

Jelmer W. Eerkens a Department of Anthropology, University of California, Davis, One Shields Avenue, Davis, CA 95616, USA (jweerkens@ucdavis.edu, corresponding author)

Eric J. Bartelink Department of Anthropology, California State University, Chico, 400 West First Street, Chico, CA 95929, USA

Julianna Bartel a Department of Anthropology, University of California, Davis, One Shields Avenue, Davis, CA 95616, USA Phillip R. Johnson a (deceased), State Historical Preservation Office, Kentucky Heritage Council, 410 High Street, Frankfort, KY 40601, USA

American Antiquity 84(2), 2019, pp. 336-352

Copyright (C) 2019 by the Society for American Archaeology doi:10.1017/aaq.2018.84 
are relatively standardized in how they are expressed, including the timing of their onset and completion, especially within the sexes, there is tremendous cultural variation in how societies practice and observe life history transitions (Crittenden and Meehan 2016).

Food and diet play an important part in the expression of these different human life history stages and transitions. For example, one of the most important and stressful transitions is the weaning process, when a young individual transitions from breast milk to solid foods (Hill and Hurtado 1996; Quinlan 2007; Trivers 1974). This is a transition that all individuals experience, typically at an early age (between a few months and a few years; though in some recent settings formula is substituted for breast milk entirely). Other stages in life may also be expressed by dietary shifts. For example, in the United States today, early adolescent years are often expressed by increased consumption of sugar-rich and highly processed foods (Ogden et al. 2011; Wang et al. 2008).

Because many life history stages are expressed culturally, bioarchaeological methods provide the best means to reconstruct them in ancient societies. In particular, stable isotope analyses are well suited to reconstructing these processes when life history transitions involve dietary or residential changes. Because human tissues, including bones and teeth, are synthesized from ingested foods, they record signatures of the paleodiet of an individual. Furthermore, teeth grow in sequential layers over windows of time. Isolating tissue from different layers, then, facilitates diachronic reconstruction of diet for an individual during the growth and development period. In other words, by analyzing different tissues that form at different points in a person's life, we can track paleodietary patterns over a number of potential life history stages. These techniques allow us to reconstruct something of an isotopic biography, or an "isobiography," for individuals from the past.

In this article, we analyze stable isotopes of carbon and nitrogen in 100 dentinal collagen samples extracted from first $(n=5)$ and third $(n=11)$ molars. A total of 16 individuals (one tooth per person) was sampled from five archaeological sites on the island of Tutuila in American
Samoa (see Figure 1). Teeth were cut in serial sample fashion to obtain a time-transgressive estimate of diet for that person during the window of time the dentinal collagen formed (see Eerkens et al. 2011). We then examine life history patterns in diet through the distribution of stable isotope values across serial sections.

\section{A Samoan Dietary Model}

Before examining ancient remains, we first establish a pattern based on ethnographic sources of dietary life history in American Samoa, focusing on information available from the late nineteenth through mid-twentieth century. Precise dietary life history data are not available for individuals, as diet was typically of secondary concern in anthropological studies on the islands, especially in earlier studies. Instead, we rely on aggregate or more general information recorded by ethnographers that relates to subsistence practices of villages and/or households. In this regard, we examine two types of information, household social organization and foraging behaviors. Although we use the past tense to connote an ethnographic past, people continue many of these behaviors today.

American Samoans were dependent on the ocean (e.g., fish, shellfish, crustaceans, sea turtles), inland agricultural fields (e.g., banana, taro, coconut, breadfruit, yams), and domesticated animals (e.g., pig, dog, chicken) for the majority of their basic subsistence. Villages were made up of a number of household economic units (5-40), often spread over large areas. While most villages in ethnohistoric times were near the coast, archaeological data indicate that inland areas were more heavily occupied in precontact times (Addison et al. 2006; Davidson 1969; Eckert and Welch 2013; Quintus and Cochrane 2017; Rieth and Addison 2008). Households within villages varied in size from nuclear families, to larger extended families, to multifamily houses, but each was presided over by a chief or matai (Ember 1962; Tcherkézoff 2000). In general, Samoan society was ranked, both households within a village and individuals within a household (Krämer 1994; Mead 1928). 


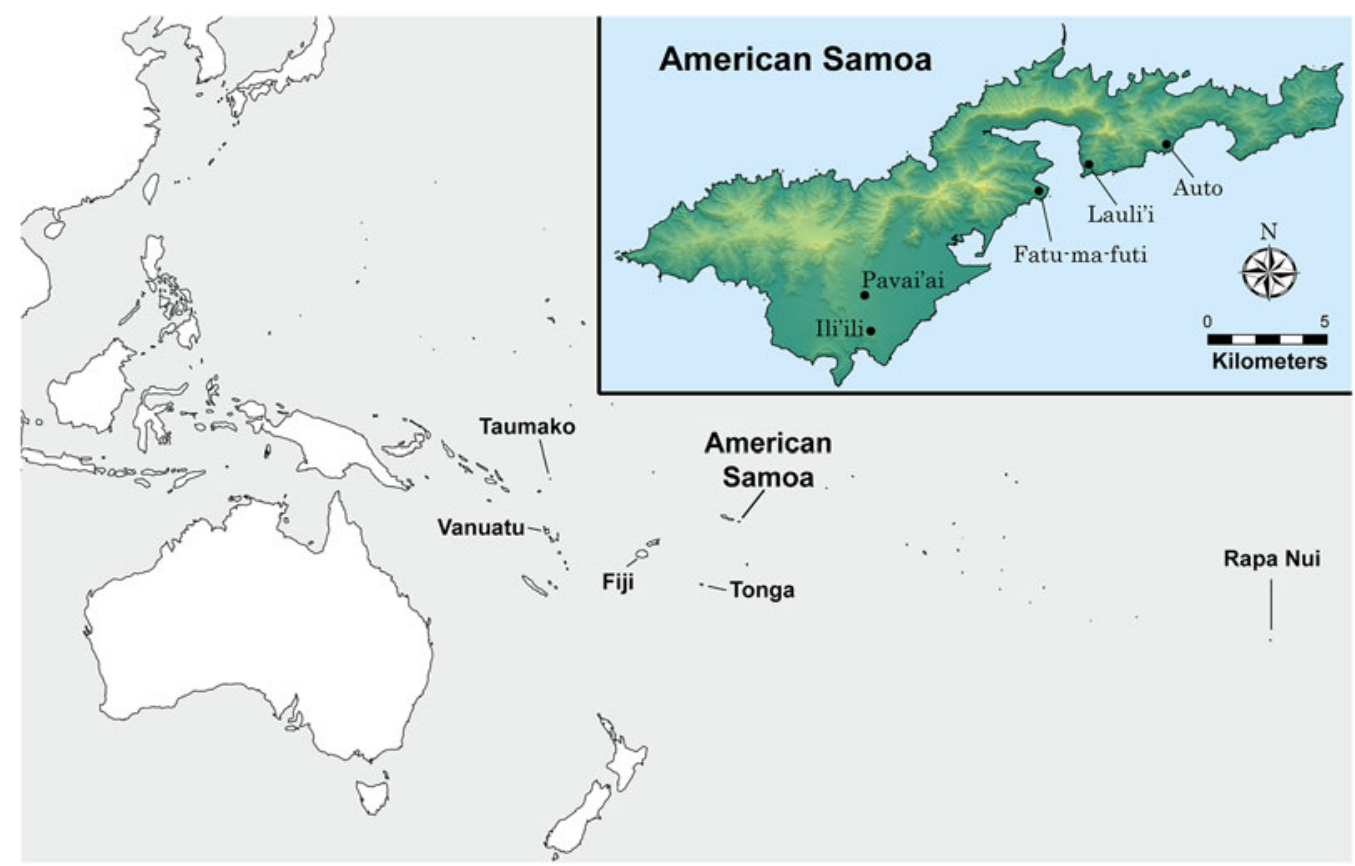

Figure 1. Map showing the location of Tutuila Island, American Samoa (inset), and sites included in this study.

As in all traditional human societies, dietary life history on American Samoa began with infants consuming breast milk. Typically within the first few months after birth, small amounts of solid or liquid food, often premasticated by the mother, were introduced to the infant (Mead 1928:21). This point marks the beginning of the weaning process, a slow transition to solid food. The precise length of time that infants consumed breast milk is not well established in ethnographic studies in American Samoa, especially prior to the twentieth century, when breastfeeding behavior was not an important topic in anthropology. More detailed studies in the 1960s through 1980s indicate that weaning was usually complete between one and two years (Bindon 1984, 1986; Gardner 1965:29; Nardi 1984). However, Nardi (1984) suggests that greater involvement in cash economies in the middle of the twentieth century in the Pacific placed a greater labor burden on women and may have promoted earlier weaning. Indeed, Malcolm notes that in earlier times women used to "breastfeed the infants until they were about two years old or even older" (1954:19), and Mead (1928:22) stated that mothers nursed their babies until they were two to three years old. Based on these observations, we expect a transition from breast milk to solid foods between two and three years of age for most individuals in precontact times. There are no suggestions of a difference in the age of weaning between boys and girls from these sources; thus, this dietary transition appears to have happened around the same time for all individuals.

Ethnographic studies of social organization in American Samoa suggest additional age-linked transitions in diet as individuals moved from adolescence into adulthood. Within households, extended families ate evening meals together, but with a particular order in which people took food from the day's harvest. Gardner (1965:14-16) observed that male heads of house typically ate first, followed by other adults and only then children. Likewise, Mead (1928:18) suggested a similar ordering, with adult males eating first, followed by women and children and finally boys (presumably adolescent boys). This partitioning in the timing of eating often resulted in many of the most desirable foods being consumed first, with lowerstatus foods left for children, especially younger 
boys and girls. These dietary differences, especially in protein intake, have been recorded in more recent studies in American Samoa as well (e.g., Bindon 1984, 1986). As a result, there was significant variation in the composition of diet by age and sex within households, especially during evening meals.

Of course, not all foods were consumed during evening meals. "Snacking" while foraging is commonly observed by anthropologists during field studies and can contribute significant numbers of calories in the diets of individuals (Ladio and Lozada 2001:368; Lupo 2006:39; Stearman 1991:253). Thus, an evaluation of foraging behavior is also warranted, especially because many researchers observed that foraging efforts were also partitioned by age and sex in American Samoa.

In a detailed survey on American Samoa in 1975, Hill (1978) documented significant agegrading in participation in subsistence activities involving marine environments. Overall, he found that males were engaged in these activities far more often than females (more than 1,100 observations over a six-month period). Of the children under age 15 years, $70 \%$ of those harvesting food from marine environments were boys; of adolescents (age 15-20 years), 75\% were male; and of adults (age 21-60 years), $69 \%$ were male. The only age category where females outnumbered males in these activities was among elderly adults over the age of 60 years, where just $37 \%$ were male. The specific types of activities undertaken by the sexes also varied and changed with age categories. Females predominantly engaged in "gleaning," defined as the gathering of sessile animals, including echinoderms, mollusks, and crustaceans. Males engaged more often in fishing, either by diving (spearfishing), hook-and-line, or using boats and nets. Young boys under age 15 years tended to engage more in gleaning (i.e., typically "female" activities) but transitioned to more fishing, or male activities, with age. Mead (1928) made similar observations on sex and age-linked foraging behaviors, though far less detailed and nonquantitative in nature.

Hill's (1978) survey also showed that the likelihood of participation in marine-focused subsistence activities was initially low for boys and girls, then increased with age through early adult years, after which it decreased again. The magnitude of increase, however, was less for females than for males, and the timing of the decrease in adulthood was earlier for males. In other words, adolescent boys and young men rapidly increased investment in fishing activities early in life but after reaching early adult years shifted most of their labor to tending gardens and raising domesticated animals (Bindon 1988; Holmes 1974). By contrast, a higher percentage of adult women continued to engage in fishing long after adolescence. Although these adult women contributed to garden production by weeding and harvesting, the success of a garden was said to depend mainly on male labor input (Bindon 1988:63). Thus, many of the highstatus foods, especially pigs, were said to derive from the labors of adult males.

If snacking was important during foraging efforts, we would expect boys and girls to synchronously increase their marine food intake after early childhood. Fully adult males should decrease their marine intake as they shifted their labor efforts to tending gardens and domesticated animals. Likewise, the snacking diets of females should be focused more on lower-trophic-level sessile invertebrates, rather than on highertrophic-level reef fish, well into adult years.

In sum, if precontact populations followed a similar dietary life history as described in ethnographic times, then we expect males and females to start life with identical diets (breast milk) and continue with similar diets during childhood, where the majority of solid foods were provisioned within the household. In adolescence, we expect a divergence by sex, where male diets should be focused more on marine fish and female diets more on marine invertebrates. Finally, as adults, males should shift toward a more terrestrial-focused diet, while females may shift slightly in this direction but maintain a greater marine focus than males.

\section{Materials}

The human remains in this study derive from various archaeological excavations undertaken by the American Samoa Power Authority (ASPA) in the villages of Fatu-ma-futi, Lauli'i, 
Ili'ili, Auto, and Pavai' ai (Bartelink and Johnson 2014), although a few burials from Fatu-ma-futi village were originally excavated through a cultural resource management firm in 2004 during a road improvement project (Kailihiwa et al. 2005). The majority of human remains were located as inadvertent discoveries during ASPA archaeological monitoring for various construction projects, including the installment of sewer lines and a septic tank. For each village, the ASPA principal investigator received permission for bioarchaeological analyses of human remains by landowners in consultation with village leadership. Table 1 lists the individuals included in this study, the tooth sampled, the number of dentin samples from that tooth, and demographic information for the individual. Stable isotope analysis on bone collagen from some of the same individuals we sampled was previously reported by Valentin and colleagues (2011). We resampled these individuals to extract bone and tooth collagen for stable isotope analysis to ensure that the tooth samples came from the same individual as the bone collagen and that data are directly comparable.

The majority of the samples (9 of 16 individuals) come from the site of Fatu-ma-futi, a coastal habitation site with significant accumulations of shellfish and fish (Addison et al. 2008; Morrison and Addison 2008, 2009). Additional samples come from the coastal sites Lauli'i $(n=2)$ and Auto $(n=1)$. The remaining four samples are from slightly inland sites; one is Pavai'ai $(n=3)$, about $3 \mathrm{~km}$ from the coast, and the other is Ili'ili $(n=1)$, about $2 \mathrm{~km}$ from the coast (Addison et al. 2006). While the earliest known evidence of human occupation of Tutuila derives from site components currently dated to around 2500 BP (Addison and Asaua 2006; Addison et al. 2006; Cochrane et al. 2013; Rieth and Hunt 2008; Rieth et al. 2008), all individuals in the study date to between 1200 and $100 \mathrm{cal} \mathrm{BP}$, as demonstrated by direct radiocarbon dates on human bone collagen (Table 1). The distribution of the radiocarbon dates in our sample does suggest some degree of clustering, with an older group of individuals dating between 1070 and $950 \mathrm{BP}(n=7)$ and a younger group between 530 and $120 \mathrm{BP}(n=9)$.

\section{Methods}

Human teeth grow in thin incremental layers, accruing dentinal tissue from the dentino-enamel junction apically over time (Hillson 1996, 2014). Each increment forms over a number of weeks to months as tissues are initially deposited and subsequently mineralized. Once deposited, these tissues do not remodel, recording isotope ratios within the tooth increments.

The ontogenetic age at which a tooth forms varies significantly by tooth type and position. In this study, we examine permanent first molars and third molars. First molars begin forming around the time of birth until about age 9.5, when the apical root closes. Third molars begin forming between 7 and 10 years of age and continue growing through age 18 to 25 years, until the root apices close (Hillson 1996, 2014).

Within a tooth it is possible to further isolate tissues that grew over different windows of time by sectioning the tooth along the axis of growth and measuring stable isotope composition within each section (e.g., Beaumont et al. 2012; Beaumont et al. 2015; Burt 2015; Eerkens and Bartelink 2013; Eerkens et al. 2011; Fuller et al. 2003). By analyzing serial samples, it is possible to reconstruct isotopic changes in diet across successive windows of time for a particular individual. Using first and third molars, we can trace paleodiet across the first and second decade of life, respectively.

Collagen extraction followed a modified Longin (1971) method. Tooth serial sampling follows procedures established by Eerkens and colleagues (Eerkens et al. 2011; Eerkens et al. 2016). Briefly, a tooth was cleaned with a small brush of any adhering soil or other exogenous material, sonicated in deionized water $\left(\mathrm{dH}_{2} \mathrm{O}\right)$, and cut in half longitudinally (i.e., crown to root) with a slow-speed diamond-coated saw. All cementum and enamel was removed, and the pulp chamber was reamed out from one half of the tooth using a handheld drill to remove secondary dentin. This tooth half was demineralized in a solution of $0.5 \mathrm{M} \mathrm{HCl}$ in a refrigerator set at $5{ }^{\circ} \mathrm{C}$. $\mathrm{HCl}$ was changed every other day until the sample was completely demineralized (generally one-two weeks). 
Table 1. Individuals Included in This Study and Associated Demographic Information.

\begin{tabular}{|c|c|c|c|c|c|c|c|c|c|c|c|c|}
\hline Site & Individual & Sex & Project ID & Provenience & $\begin{array}{c}\text { Depth below } \\
\text { Surface (cm BS) }\end{array}$ & $\begin{array}{l}\text { Age at } \\
\text { Death }\end{array}$ & Tooth & $\begin{array}{l}\text { \# Isotope } \\
\text { Samples }\end{array}$ & $\begin{array}{l}\text { AMS Date } \\
\text { BP }\end{array}$ & $\begin{array}{c}\delta^{13} \mathrm{C} \text { Bone } \\
\text { Collagen }\end{array}$ & $\begin{array}{l}\text { Calibrated Age } \\
\text { BP }(2 \sigma)\end{array}$ & AMS Lab \# \\
\hline Fatu-ma-futi & $\mathrm{B} 5^{\mathrm{a}}$ & Infant & AS-25-062 & Unit 19 & 99 & $1-2$ & LLM1 & 3 & $1065 \pm 34$ & -17.8 & $920-760$ & WK-18056 \\
\hline Fatu-ma-futi & $\mathrm{B} \mathrm{A}^{\mathrm{a}}$ & Infant & AS-25-062 & Unit 13 & 99 & $2-4$ & LRM1 & 3 & $1045 \pm 31$ & -17.1 & $900-730$ & WK-18057 \\
\hline Fatu-ma-futi & Feature $2^{\mathrm{b}}$ & Juvenile & AS-25-062 & Unit 1, Layer III & 53 & $5-7$ & LRM1 & 5 & $980 \pm 40$ & -17.5 & $800-670$ & Beta-193873 \\
\hline Pavai’ai & $\mathrm{B} 1 \mathrm{~B}$ & Juvenile & AA2008-2 & $\begin{array}{l}\text { Pavai'ai Sewer } \\
\text { P-9, Profile } 1\end{array}$ & Unknown & $8-9$ & ULM1 & 5 & $218 \pm 30$ & -16.9 & $250-0$ & WK-27044 \\
\hline Fatu-ma-futi & B2 & Juvenile & AS-25-062 & Unit 43 & 40 & $12-18$ & LLM3 & 4 & $475 \pm 31$ & -17.9 & $470-310$ & WK-18054 \\
\hline Fatu-ma-futi & $\begin{array}{c}\text { Feature } \\
1 \mathrm{~A}^{\mathrm{b}}\end{array}$ & Female & AS-25-062 & Unit 1/3, Layer III & 67 & $20-23$ & LLM3 & 7 & $1030 \pm 40$ & -18.6 & $910-730$ & Beta-193871 \\
\hline Fatu-ma-futi & $\begin{array}{c}\text { Feature } \\
1 \mathrm{~B}^{\mathrm{b}}\end{array}$ & Female & AS-25-062 & Unit 1/3, Layer III & 69 & $18+$ & LLM3 & 9 & $1050 \pm 40$ & -18.3 & $910-730$ & Beta-193872 \\
\hline Fatu-ma-futi & $\mathrm{B} 7^{\mathrm{a}}$ & Female & AS-25-062 & Unit 13/7 & 91 & $18+$ & URM3 & 7 & $1067 \pm 31$ & -17.2 & $910-750$ & WK-18058 \\
\hline Pavai’ai & B1A & Female & AA2008-2 & $\begin{array}{l}\text { Pavai'ai Sewer } \\
\text { P-9, Profile } 1\end{array}$ & Unknown & $25-34$ & LRM3 & 6 & $241 \pm 30$ & -16.7 & $280-0$ & WK-27053 \\
\hline Pavai'ai & B2 & Female & AA2008-2 & $\begin{array}{l}\text { Pavai'ai Sewer } \\
\text { P-9, Profile } 1\end{array}$ & Unknown & $18-29$ & URM3 & 9 & $118 \pm 30$ & -17.6 & $250-0$ & WK-27042 \\
\hline Auto & B2A & Male & AA2005-11 & $\begin{array}{l}\text { West trench } \\
\text { (septic tank) }\end{array}$ & Unknown & $18+$ & ULM1 & 10 & $229 \pm 30$ & -16.3 & $250-0$ & WK-27049 \\
\hline Fatu-ma-futi & B3 & Male & AS-25-062 & Unit 41 & 39 & $18-29$ & ULM3 & 10 & $516 \pm 33$ & -19.1 & $470-310$ & WK-18055 \\
\hline Fatu-ma-futi & B4 & Male & AS-25-062 & Unit 37 & 86 & $12-18$ & ULM3 & 4 & $973 \pm 30$ & -18.0 & $970-680$ & WK-25790 \\
\hline Ili'ili & B1 & Male & AA2004-15 & $\begin{array}{l}\text { Main I, MH \#I67 } \\
\text { (sewer) }\end{array}$ & $45-55$ & $18+$ & URM3 & 3 & $197 \pm 30$ & -18.4 & $240-0$ & WK-27040 \\
\hline Lauli'i & $\mathrm{B} 4^{\mathrm{a}}$ & Male & AA2005-11 & $\begin{array}{l}\text { Layer IV, South } \\
\text { Wall }\end{array}$ & $82-91$ & $40+$ & URM3 & 9 & $499 \pm 33$ & -18.2 & $490-330$ & WK-18856 \\
\hline Lauli’i & B5 & Indeterminate & AA2005-11 & West/North Wall & Unknown & $18+$ & URM3 & 6 & $437 \pm 30$ & -18.6 & $450-300$ & WK-27055 \\
\hline
\end{tabular}

Note: AMS = accelerator mass spectrometry. Unless otherwise noted, AMS samples submitted by P. R. Johnson and Q. Winterhoff (American Samoa Power Authority) to Waikato Radiocarbon Dating Laboratory.

${ }^{a}$ Waikato Radiocarbon Dating Laboratory dates reported in Valentin et al. (2011).

${ }^{\mathrm{b}}$ Beta Analytic dates reported in Kailihiwa et al. (2005). 
The tooth was then rinsed with $\mathrm{dH}_{2} \mathrm{O}$ and sliced into parallel, horizontally oriented serial sections, beginning at the apical root tip and working up toward the crown. These cuts are parallel to growth layers within the crown but cut across diagonal growth layers in the root (see Eerkens et al. 2011). Because layers accumulate in a cone-like manner within the root, we were unable to manually cut cones out of the demineralized root but had to cut horizontally across growth planes. As a result, adjacent serial samples in the root include some material from the same layers of growth (i.e., adjacent sections do not represent mutually exclusive temporal windows). This will cause fluctuations of stable isotope data to be somewhat smoothed within increments of the root sections. We estimate that every other sample within the root has less than $10 \%$ of the same (synchronous) material, by volume. The number of serial sections produced varied slightly by tooth depending on the degree of occlusal wear, as well as the size, length, and structure of the tooth.

Following demineralization, any secondary dentin that was not reamed out during drilling was also removed manually (typically it separates from the primary dentin). Following sectioning, each serial sample was placed in a separate vial and immersed in $0.125 \mathrm{M} \mathrm{NaOH}$ for 24 hours to remove humic acids. The sample was rinsed with $\mathrm{dH}_{2} \mathrm{O}$ to remove any residual $\mathrm{NaOH}$ and placed in slightly acidic $\mathrm{pH} 3$ water in an oven set to $70{ }^{\circ} \mathrm{C}$ to solubilize collagen. Solubilized collagen was then freeze-dried to remove all remaining water, isolating the collagen fraction.

Approximately $1.0 \mathrm{mg}$ of collagen was weighed out from each serial section for stable isotope analysis. In some cases, there was not enough collagen from a serial sample, and one or two adjacent sections were combined to achieve a total of $1 \mathrm{mg}$. Carbon $\left({ }^{13} \mathrm{C} /{ }^{12} \mathrm{C}\right)$ and nitrogen $\left({ }^{15} \mathrm{~N} /{ }^{14} \mathrm{~N}\right)$ isotope ratios for each serial sample were measured by continuous-flow mass spectrometry (PDZ Europa ANCA-GSL elemental analyzer interfaced to a PDZ Europa 20-20 isotope ratio mass spectrometer) at the Stable Isotope Facility, University of California, Davis. Carbon isotope ratios are reported using the delta notation $\left(\delta^{13} \mathrm{C}\right)$ and expressed in parts per thousand (permil, \%o) relative to the Vienna Pee Dee Belemnite standard (arbitrarily set at $0 \%$ ). Similarly, nitrogen isotope ratios are reported using the delta notation $\left(\delta^{15} \mathrm{~N}\right)$ and expressed against $\mathrm{N}_{2}$ in modern atmospheric air (also arbitrarily set to 0\%o). Repeated analyses of standards with known isotopic composition show that internal instrument precision is less than $0.1 \%$ or for $\delta^{13} \mathrm{C}$ and less than $0.2 \%$ ofor $\delta^{15} \mathrm{~N}$.

In paleodietary studies, carbon isotopes provide an estimate of the consumption of $\mathrm{C}_{3}$ versus $\mathrm{C}_{4}$ plants and marine foods (Cerling et al. 1998; Ehleringer et al. 1991; Farquhar et al. 1989). In American Samoa, $\delta^{13} \mathrm{C}$ primarily provides an estimate of the importance of marine versus terrestrial foods (Schoeninger et al. 1983). $\mathrm{C}_{4}$ plants, such as sugarcane (Saccharum officinarum), may have been available prehistorically, although conclusive evidence is lacking for American Samoa. Furthermore, sea grapes (Caulerpa racemosa), a type of macro-algae, follow a $\mathrm{C}_{4}$ pathway (Casu et al. 2009) and were likely consumed in prehistoric American Samoa. Despite the potential availability of these $\mathrm{C} 4$ resources, they are poor sources of dietary protein and thus are expected to be underrepresented in collagen isotope signatures (Leach et al. 1996). Nitrogen isotopes reflect the general trophic level of consumed foods. Nitrogen fractionates during the synthesis of biological tissues, favoring the retention of the heavier ${ }^{15} \mathrm{~N} . \delta^{15} \mathrm{~N}$ increases by about $3 \%$-6\% with each trophic level (Minagawa and Wada 1984; O'Connell et al. 2012; Schoeninger 1985). In most island terrestrial systems, there are three trophic levels-plants, herbivores, and carnivores. In aquatic environments there are more trophic levels, resulting in greater enrichment of ${ }^{15} \mathrm{~N}$ at the top of the food chain (Minagawa and Wada 1984; Schoeninger 1985). The latter include large fish, predatory birds, and aquatic mammals.

In humans, collagen is synthesized mainly from consumed protein (Ambrose and Norr 1993; Kellner and Schoeninger 2007; Tieszen and Fagre 1993). A recent study estimates that $72 \%$ of the carbon in collagen comes from dietary protein, with the remaining $28 \%$ derived from carbohydrates and lipids (Fernandes et al. 2012). Combined, $\delta^{13} \mathrm{C}$ and $\delta^{15} \mathrm{~N}$ of human collagen can be used to discriminate foraging 
patterns, especially for dietary protein, in different environments. In general, foraging in coastal environments leads to elevated $\delta^{13} \mathrm{C}$ values. Because nitrogen isotopes fractionate with each trophic level and marine environments tend to have more trophic levels, $\delta^{15} \mathrm{~N}$ values also tend to be elevated in these settings. By contrast, foraging in terrestrial environments leads to lower $\delta^{13} \mathrm{C}$ and $\delta^{15} \mathrm{~N}$ isotope values, and brackish water and some reef environments lead to intermediate, but still distinctive, values (Eerkens et al. 2013).

A comparison of published bone collagen stable isotope values among different Pacific Island groups from Fiji, Solomon Islands, Vanuatu, Rapa Nui, and Tonga shows distinctive ranges of $\delta^{13} \mathrm{C}$ and $\delta^{15} \mathrm{~N}$ values for many island populations. Figure 2 plots $\delta^{13} \mathrm{C}$ and $\delta^{15} \mathrm{~N}$ for six different populations (data from Commendador et al. 2013; Kinaston et al. 2013; Kinaston et al. 2014; Stantis et al. 2016; Valentin et al. 2010; Valentin et al. 2011). Inhabitants of Tutuila, American Samoa, have lower $\delta^{13} \mathrm{C}$ and $\delta^{15} \mathrm{~N}$ values compared with other island groups (Figure 2). This is consistent with the general interpretation that American Samoan diets were focused more on lower-trophic-level terrestrial foods, especially $\mathrm{C}_{3}$ plants, rather than on marine resources. Such foods included common $\mathrm{C}_{3}$ plant domesticates (bananas, taro, coconuts, breadfruit, yams), as well as domesticated animals (pig, dog, and chicken) and some wild animals (frugivorous bats) that feed on local terrestrial plants. The smaller marine component of the diet would have included reef and pelagic fish, shellfish, crustaceans, and sea turtle.

One additional potential source of isotopic variation is artificial manipulation of soils by humans, for example, through fertilizing agricultural fields with exogenous materials. Thus, Jarman and colleagues (2017) suggest that the higher $\delta^{15} \mathrm{~N}$ but lower $\delta^{13} \mathrm{C}$ values observed among humans from Rapa Nui are due to the addition of guano, household waste, and/or lithic mulch to gardens. Lacking other sources of information, it is difficult to account for these practices on a site-by-site basis. In this study, we assume that fertilizing practices were similar between different sites and time periods, at least on Tutuila. As a result, all individuals on the island should have experienced similar baseline $\delta^{15} \mathrm{~N}$ and $\delta^{13} \mathrm{C}$, and variation in these values in collagen should reflect differences in diet, not differences in field fertilization. We acknowledge this shortcoming and suggest that future research examine whether fertilization practices varied over space or changed over time on the island (see also Quintus and Cochrane 2017).

Relevant to the discussion below, in an analysis of archaeological burials from American Samoa, Valentin and colleagues (2011) report that the mean bulk $\delta^{13} \mathrm{C}$ in the bone collagen of adult females is $-18.2 \pm 0.5 \%$ o (one standard deviation; $n=8$ ), while bulk $\delta^{15} \mathrm{~N}$ values have a mean of $10.7 \pm 0.6 \%$ o (one standard deviation). Males are similar, with a mean $\delta^{13} \mathrm{C}$ of $-18.6 \pm$ $0.6 \%$ o (one standard deviation; $n=8$ ) and a mean $\delta^{15} \mathrm{~N}$ of $9.6 \pm 0.9$ (one standard deviation). Furthermore, although the number of radiocarbondated burials was small $(n=12)$, the Valentin study suggested a slight change in stable isotope values over time. Individuals dating around 1000 $\mathrm{BP}$ seem to show slightly higher $\delta^{13} \mathrm{C}$ compared with those dating younger than $600 \mathrm{BP}$, suggesting a shift from a more marine-focused to a more terrestrial-focused diet over time.

For the current study, we have expanded the number of burials sampled from Tutuila. In many cases, we resampled the same individuals reported in Valentin and colleagues (2011) in order to ensure that tooth samples were directly associated with bone (and radiocarbon dates). Because many of these burials were commingled, we were able to identify and sample additional individuals not included in the Valentin study. We were also able to sample several additional burials housed at the American Samoa Power Authority, as well as four burials that were on loan through Texas A\&M University from an earlier excavation project at Fatuma-futi. To ensure data comparability, we use our complete analyzed dataset from human bone collagen to compare with our dentin serial samples.

\section{Results}

Table 2 provides all the stable isotope values for the 100 serial samples. No obvious dietary differences are apparent between the two slightly 


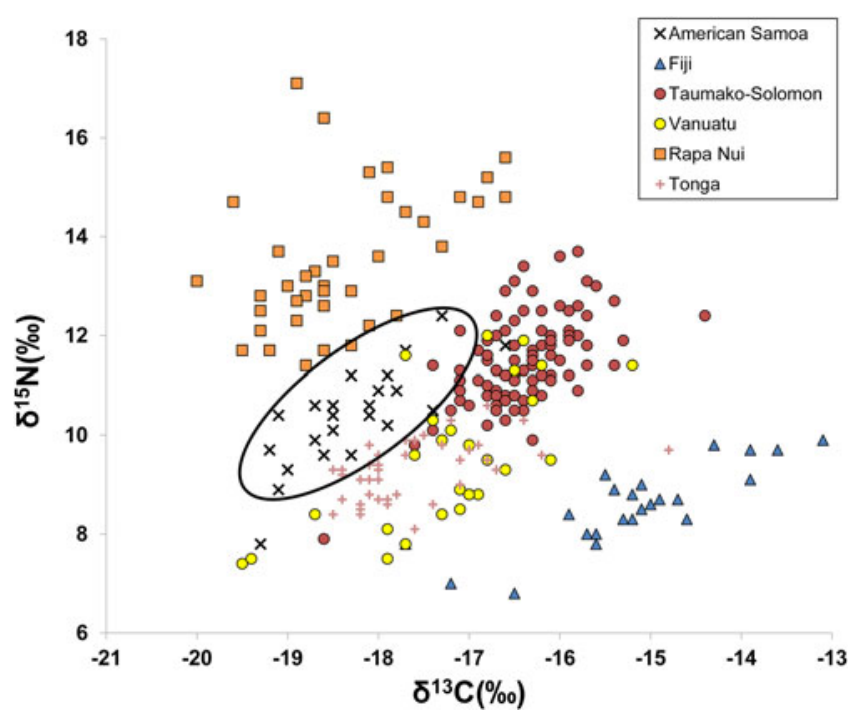

Figure 2. $\delta^{13} \mathrm{C}$ and $\delta^{15} \mathrm{~N}$ from bulk bone collagen reported in six previous Pacific Island studies (Commendador et al. 2013; Kinaston et al. 2013; Kinaston et al. 2014; Stantis et al. 2016; Valentin et al. 2010; Valentin et al. 2011), with ellipse highlighting the distinctive American Samoa signature.

inland sites (Ili'ili and Pavai'ai) and the coastal sites (Lauli'i, Auto, and Fatu-ma-futi). For example, the average values in third molars of the two inland females for $\delta^{13} \mathrm{C}(-17.3 \%$ ) and $\delta^{15} \mathrm{~N}(12.4 \%$ ) are similar to those for three females from coastal villages $\left(\delta^{13} \mathrm{C}=-17.6 \%\right.$; $\delta^{15} \mathrm{~N}=12.0 \%$ o). Likewise, one inland male averages $-17.4 \%$ and $11.4 \%$ for $\delta^{13} \mathrm{C}$ and $\delta^{15} \mathrm{~N}$, respectively, while four coastal males average $-18.1 \%$ and $11.3 \%$ for $\delta^{13} \mathrm{C}$ and $\delta^{15} \mathrm{~N}$.

In addition, there do not appear to be significant differences in isotopic values by archaeological age. If we group the burials by those dating older than $900 \mathrm{BP}$ versus those younger than $600 \mathrm{BP}$, similar to the temporal division suggested by Valentin and colleagues (2011), we do not see significant isotopic changes across time. Thus, $\delta^{13} \mathrm{C}$ and $\delta^{15} \mathrm{~N}$ values in third molars for females dating older than $900 \mathrm{BP}$ are $-17.6 \%$ and $12.0 \%$, respectively, while females younger than $600 \mathrm{BP}$ show average values of $-17.3 \%$ and $12.4 \%$. Likewise, males dating older than $1000 \mathrm{BP}$ show average values of $-18.2 \%$ and $11.5 \%$, while males dating younger than $600 \mathrm{BP}$ show average values of $-18.0 \%$ and $11.3 \%$ or $\delta^{13} \mathrm{C}$ and $\delta^{15} \mathrm{~N}$, respectively. Note that these results do not necessarily indicate a lack of dietary change through time in Tutuila. The results only suggest that any such effects on collagen stable isotope signatures are minor when compared with other sources of variation. However, the dietary shift reported by Valentin and colleagues (2011) toward the increased use of terrestrial resources through time is not supported by our expanded dataset.

In short, the minor differences by site and archaeological age explain only a small percentage of the total isotopic variation in our dataset. Instead, the major sources of variation appear to be by sex and tooth type. Because they represent different periods in life, we separate reporting of results by tooth type below.

\section{First Molars}

The five permanent first molars provide estimates on infant and early childhood dietary patterns (Figure 3). Two of the individuals from Fatuma-futi (B5 and B6) died at approximately two years of age. These teeth were incomplete at the time of death and only include the earliestforming part of the crown, and the serial samples represent less than two years of diet. Both individuals display elevated $\delta^{15} \mathrm{~N}$ values, $3.3 \%$ and $4.5 \%$ o higher than the mean value $(10.6 \%$ o of bone collagen among adult females from American Samoa. Such a signature is consistent with 
Table 2. $\delta^{13} \mathrm{C}, \delta^{15} \mathrm{~N}$, and $\mathrm{C} / \mathrm{N}$ for All Serial Samples in the Study, along with Median Estimated Age for Each Section.

\begin{tabular}{|c|c|c|c|c|}
\hline $\begin{array}{l}\text { Site and } \\
\text { Individual }\end{array}$ & $\begin{array}{c}\text { Median Age } \\
\text { (years) }\end{array}$ & $\delta^{13} \mathrm{C}$ & $\delta^{15} \mathrm{~N}$ & $\begin{array}{l}\mathrm{C} / \\
\mathrm{N}\end{array}$ \\
\hline Auto, B2A & 8.9 & -17.1 & 12.0 & 3.1 \\
\hline Auto, B2A & 7.8 & -16.8 & 11.6 & 3.1 \\
\hline Auto, B2A & 6.9 & -17.0 & 11.7 & 3.1 \\
\hline Auto, B2A & 6.0 & -17.0 & 11.9 & 3.1 \\
\hline Auto, B2A & 5.1 & -16.8 & 11.9 & 3.1 \\
\hline Auto, B2A & 4.1 & -16.8 & 12.3 & 3.1 \\
\hline Auto, B2A & 3.2 & -16.7 & 12.6 & 3.1 \\
\hline Auto, B2A & 2.3 & -16.6 & 12.5 & 3.1 \\
\hline Auto, B2A & 1.4 & -17.2 & 12.3 & 3.1 \\
\hline Auto, B2A & 0.5 & -17.3 & 13.7 & 3.1 \\
\hline Fatu, B2 & 16.9 & -17.1 & 11.5 & 3.3 \\
\hline Fatu, B2 & 14.7 & -18.0 & 10.5 & 3.1 \\
\hline Fatu, B2 & 12.5 & -17.9 & 10.8 & 3.1 \\
\hline Fatu, B2 & 10.3 & -18.5 & 9.9 & 3.2 \\
\hline Fatu, B3 & 20.7 & -19.4 & 10.3 & 3.2 \\
\hline Fatu, B3 & 19.3 & -18.3 & 12.2 & 3.2 \\
\hline Fatu, B3 & 18.2 & -18.2 & 11.8 & 3.2 \\
\hline Fatu, B3 & 17.0 & -18.2 & 11.4 & 3.1 \\
\hline Fatu, B3 & 15.8 & -18.4 & 11.0 & 3.2 \\
\hline Fatu, B3 & 14.4 & -18.4 & 11.0 & 3.1 \\
\hline Fatu, B3 & 12.5 & -18.8 & 10.2 & 3.2 \\
\hline Fatu, B3 & 11.3 & -19.4 & 10.6 & 3.1 \\
\hline Fatu, B3 & 10.5 & -19.4 & 10.4 & 3.2 \\
\hline Fatu, B3 & 10.1 & -19.5 & 10.9 & 3.2 \\
\hline Fatu, B4 & 18.7 & -18.3 & 11.6 & 3.2 \\
\hline Fatu, B4 & 16.5 & -18.2 & 11.6 & 3.1 \\
\hline Fatu, B4 & 14.4 & -18.2 & 11.2 & 3.2 \\
\hline Fatu, B4 & 11.3 & -18.0 & 11.7 & 3.2 \\
\hline Fatu, B5 & 0.5 & -17.7 & 13.9 & 3.1 \\
\hline Fatu, B5 & 1.2 & -17.8 & 13.9 & 3.2 \\
\hline Fatu, B5 & 2.0 & -17.8 & 13.8 & 3.2 \\
\hline Fatu, B7 & 20.6 & -17.4 & 13.2 & 3.2 \\
\hline Fatu, B7 & 19.2 & -17.7 & 13.4 & 3.1 \\
\hline Fatu, B7 & 18.1 & -18.1 & 13.2 & 3.1 \\
\hline Fatu, B7 & 16.9 & -18.0 & 12.8 & 3.1 \\
\hline Fatu, B7 & 15.6 & -17.8 & 13.1 & 3.1 \\
\hline Fatu, B7 & 14.6 & -17.9 & 12.6 & 3.1 \\
\hline Fatu, B7 & 11.1 & -17.8 & 12.6 & 3.1 \\
\hline Fatu, Feature 1A & 20.7 & -18.0 & 12.6 & 3.1 \\
\hline Fatu, Feature 1A & 18.8 & -18.0 & 11.8 & 3.2 \\
\hline Fatu, Feature $1 \mathrm{~A}$ & 18.2 & -18.0 & 11.6 & 3.1 \\
\hline Fatu, Feature $1 \mathrm{~A}$ & 17.0 & -18.1 & 11.8 & 3.2 \\
\hline Fatu, Feature 1A & 15.8 & -18.0 & 11.5 & 3.2 \\
\hline Fatu, Feature 1A & 14.1 & -17.7 & 11.5 & 3.2 \\
\hline Fatu, Feature 1A & 12.4 & -17.8 & 11.7 & 3.2 \\
\hline Fatu, Feature 1B & 20.8 & -17.8 & 11.5 & 3.1 \\
\hline Fatu, Feature 1B & 18.7 & -17.7 & 11.0 & 3.1 \\
\hline Fatu, Feature 1B & 16.6 & -17.5 & 11.2 & 3.1 \\
\hline Fatu, Feature 1B & 15.3 & -17.4 & 11.2 & 3.1 \\
\hline Fatu, Feature 1B & 14.5 & -17.2 & 10.9 & 3.1 \\
\hline Fatu, Feature 1B & 13.4 & -17.0 & 11.6 & 3.1 \\
\hline Fatu, Feature 1B & 12.0 & -16.9 & 11.7 & 3.2 \\
\hline Fatu, Feature 1B & 10.9 & -16.5 & 12.1 & 3.2 \\
\hline Fatu, Feature 1B & 10.2 & -16.8 & 12.5 & 3.1 \\
\hline
\end{tabular}

Table 2. Continued.

\begin{tabular}{|c|c|c|c|c|}
\hline $\begin{array}{l}\text { Site and } \\
\text { Individual }\end{array}$ & $\begin{array}{l}\text { Median Age } \\
\text { (years) }\end{array}$ & $\delta^{13} \mathrm{C}$ & $\delta^{15} \mathrm{~N}$ & $\begin{array}{l}\mathrm{C} / \\
\mathrm{N}\end{array}$ \\
\hline Fatu, Feature 2 & 1.4 & -16.9 & 13.2 & 3.2 \\
\hline Fatu, Feature 2 & 3.6 & -17.2 & 11.4 & 3.1 \\
\hline Fatu, Feature 2 & 4.0 & -17.5 & 10.8 & 3.2 \\
\hline Fatu, Feature 2 & 4.7 & -17.0 & 10.8 & 3.2 \\
\hline Fatu, Feature 2 & 5.5 & -16.9 & 11.2 & 3.2 \\
\hline Fatu, 6A & 0.3 & -17.2 & 15.1 & 3.1 \\
\hline Fatu, 6A & 0.9 & -17.0 & 15.1 & 3.2 \\
\hline Fatu, 6A & 1.7 & -16.8 & 15.3 & 3.2 \\
\hline Ili' ili, B1 & 20.2 & -17.7 & 11.3 & 3.1 \\
\hline Ili'ili, B1 & 16.5 & -17.5 & 11.4 & 3.1 \\
\hline Ili'ili, B1 & 11.3 & -17.2 & 11.6 & 3.2 \\
\hline Lauli'i, B4 & 20.5 & -18.7 & 10.7 & 3.2 \\
\hline Lauli’i, B4 & 19.3 & -18.7 & 10.6 & 3.1 \\
\hline Lauli’i, B4 & 18.4 & -18.3 & 10.3 & 3.2 \\
\hline Lauli’i, B4 & 17.0 & -18.5 & 10.0 & 3.1 \\
\hline Lauli'i, B4 & 15.6 & -19.1 & 10.1 & 3.2 \\
\hline Lauli’i, B4 & 14.8 & -18.7 & 10.1 & 3.2 \\
\hline Lauli'i, B4 & 14.0 & -18.5 & 10.4 & 3.2 \\
\hline Lauli'i, B4 & 13.2 & -18.2 & 10.9 & 3.2 \\
\hline Lauli'i, B4 & 12.5 & -18.0 & 10.8 & 3.1 \\
\hline Lauli’i, B5 & 19.9 & -19.2 & 10.3 & 3.1 \\
\hline Lauli’i, B5 & 19.2 & -19.2 & 10.4 & 3.2 \\
\hline Lauli'i, B5 & 17.9 & -19.0 & 10.2 & 3.3 \\
\hline Lauli'i, B5 & 16.6 & -18.7 & 10.3 & 3.2 \\
\hline Lauli'i, B5 & 15.3 & -18.5 & 10.4 & 3.2 \\
\hline Lauli’i, B5 & 11.5 & -18.4 & 11.4 & 3.1 \\
\hline Pavai'ai, B1A & 18.9 & -18.3 & 11.4 & 3.1 \\
\hline Pavai'ai, B1A & 15.0 & -17.4 & 12.7 & 3.2 \\
\hline Pavai'ai, B1A & 14.0 & -17.2 & 13.4 & 3.1 \\
\hline Pavai'ai, B1A & 12.8 & -16.7 & 14.7 & 3.1 \\
\hline Pavai'ai, B1A & 11.7 & -16.2 & 15.0 & 3.1 \\
\hline Pavai'ai, B1A & 10.7 & -16.2 & 15.2 & 3.1 \\
\hline Pavai'ai, B1B & 6.0 & -16.4 & 11.9 & 3.1 \\
\hline Pavai'ai, B1B & 4.4 & -16.1 & 12.1 & 3.1 \\
\hline Pavai'ai, B1B & 3.0 & -15.9 & 12.6 & 3.2 \\
\hline Pavai'ai, B1B & 1.8 & -16.3 & 13.5 & 3.1 \\
\hline Pavai'ai, B1B & 0.6 & -16.8 & 13.6 & 3.1 \\
\hline Pavai'ai, B2 & 20.9 & -18.1 & 11.4 & 3.2 \\
\hline Pavai'ai, B2 & 20.0 & -18.0 & 10.9 & 3.2 \\
\hline Pavai’ai, B2 & 19.1 & -17.7 & 11.3 & 3.1 \\
\hline Pavai'ai, B2 & 18.3 & -17.6 & 11.2 & 3.2 \\
\hline Pavai'ai, B2 & 17.5 & -17.4 & 11.4 & 3.1 \\
\hline Pavai'ai, B2 & 16.8 & -16.9 & 11.8 & 3.2 \\
\hline Pavai’ai, B2 & 16.1 & -17.0 & 11.7 & 3.1 \\
\hline Pavai'ai, B2 & 15.3 & -17.3 & 11.8 & 3.2 \\
\hline Pavai’ai, B2 & 14.3 & -16.8 & 12.0 & 3.2 \\
\hline
\end{tabular}




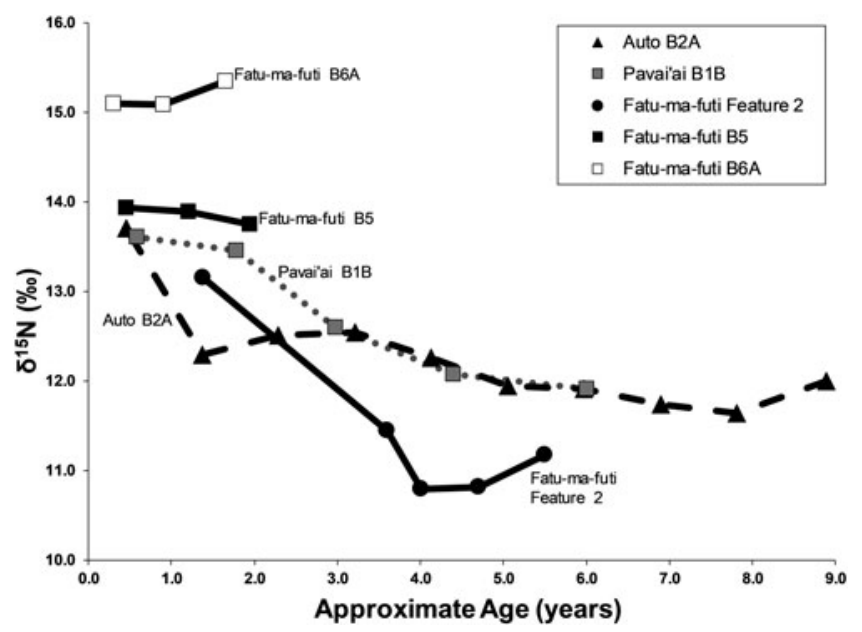

Figure 3. $\delta^{15} \mathrm{~N}$ in permanent first molar serial sections for five individuals from American Samoa, plotted by estimated median age of each section.

one full trophic level above adult values, as would be expected for an infant who was receiving all of his or her protein through breastfeeding. $\delta^{15} \mathrm{~N}$ values do not decrease significantly throughout the serial sections, suggesting that both toddlers were still receiving most or all of their protein from breast milk at the time of death.

The other three individuals had more complete first molars, with dentin extending into the roots, facilitating the reconstruction of longer dietary life histories. Still, one individual from Fatu-ma-futi (Feature 2) and one from Pavai'ai (B1B) died between six and eight years of age, before the apical root closed, and our serial samples extend out to only age 5.5 and 6.0 years, respectively. The third individual, from Auto (B2A), had a complete first molar and had lived into adulthood. The teeth from these three individuals also show elevated $\delta^{15} \mathrm{~N}$ values in the coronal dentin but much lower values within the lower sections of the crown and into the root. This is consistent with a weaning process. From these results, we conclude that the three individuals were completely weaned before ages $4.0,4.4$, and 1.4 years, respectively (mean $=3.3$ years).

By contrast, intra-M1 and interindividual variation is less pronounced for $\delta^{13} \mathrm{C}$. The mean intratooth range (maximum-minimum) for $\delta^{13} \mathrm{C}$ is just $0.6 \%$, compared with $1.3 \%$ o for $\delta^{15} \mathrm{~N}$. Likewise, the standard deviation of intratooth averages, a measure of interindividual variation, is $0.5 \%$ o for $\delta^{13} \mathrm{C}$, compared with $1.4 \%$ o for $\delta^{15} \mathrm{~N}$. The lower variation in $\delta^{13} \mathrm{C}$ suggests a fairly steady and consistent mixture of terrestrial and marine-derived protein for all children in the sample. Relative to adult bone collagen values with an average of $-18.3 \%$, $\delta^{13} \mathrm{C}$ is elevated in M1 teeth, averaging $-16.9 \%$. This suggests that children consumed higher amounts of marine-derived protein compared with adults in the sample.

\section{Third Molars}

Eleven third molars provide additional evidence on dietary patterns during the second decade of life on American Samoa. As shown in Figures 4 and 5, there is a clear difference between males and females during this window of life, especially for $\delta^{13} \mathrm{C}$ values, which are elevated for females, particularly between 10 and 15 years of age. While male $\delta^{13} \mathrm{C}$ values are relatively stable during the second decade of life, $\delta^{13} \mathrm{C}$ values decrease notably with age for females, only approaching the male average around 20 years of age. This suggests that the dietary pattern observed in first molars, where children seem to consume greater amounts of marine foods, changes for males around age 10 but continues for females throughout much of the second decade of life. Given the overall sexlinked dietary patterns evident in the data, the 

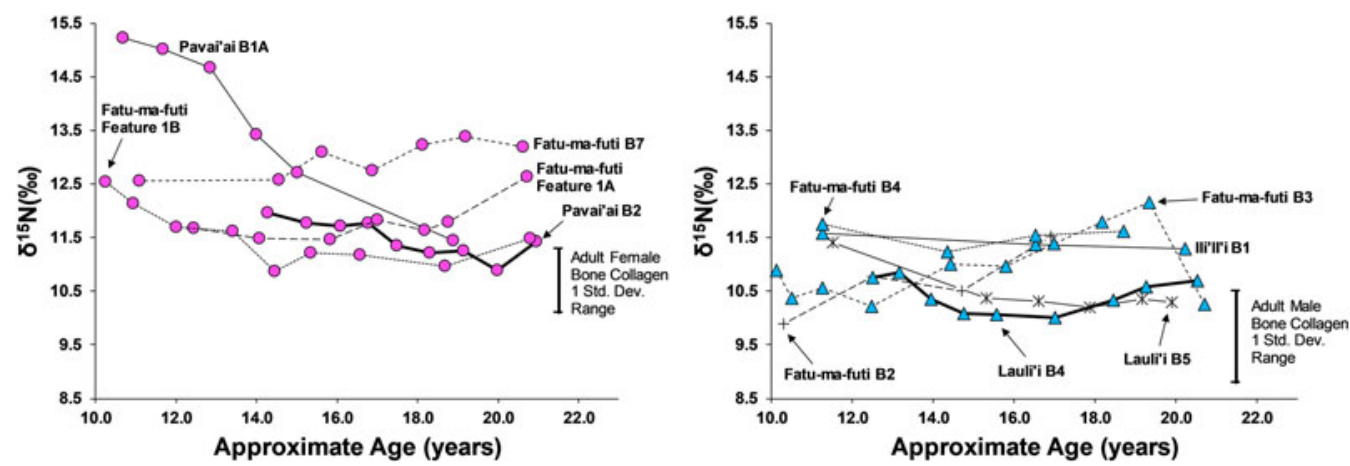

Figure 4. $\delta^{15} \mathrm{~N}$ in serial sections of third molars from American Samoa for females (left) and males and suspected males (right), with one standard deviation range for adult male and female bone collagen.

two individuals that are indeterminate for sex (Burial 5 from Lauli'i and Burial 2 from Fatu-ma-futi; plotted with males in Figures 4 and 5) have a more male-like dietary pattern.

\section{Discussion}

Results from the present study did not identify a significant dietary change between 1200 and 100 cal BP, suggesting that isotopically similar food resources were consumed through time. Contrary to previous isotope data on a smaller set of samples suggesting that human paleodiets became more terrestrially focused over time in Tutuila (Valentin et al. 2011), our expanded isotope sample suggests dietary stability between 1200 and 100 BP. Some zooarchaeological studies from the Samoan archipelago have also failed to identify significant changes in faunal assemblages, implying that human populations did not have a large negative impact on the relative abundance or diversity of species (Morrison and Addison 2008, 2009; Nagaoka 1993). This was true of both fish and invertebrate species (shellfish), which showed few changes in relative abundance and species diversity through time. However, Morrison and Addison (2009) found evidence for a significant decline in the trophic level of fish species at Fatu-ma-futi between 300 and $100 \mathrm{BP}$, which could reflect human-induced harvest pressure or could have been caused by environmental changes. A fruitful line of research for the future would be to further test this proposed diachronic dietary change (or lack thereof) by examining isotopes in samples from additional sites on the island.

We were able to estimate a maximum age for the termination of breast milk for three individuals on Tutuila, American Samoa. Based on a drop in $\delta^{15} \mathrm{~N}$ values from the coronal to root
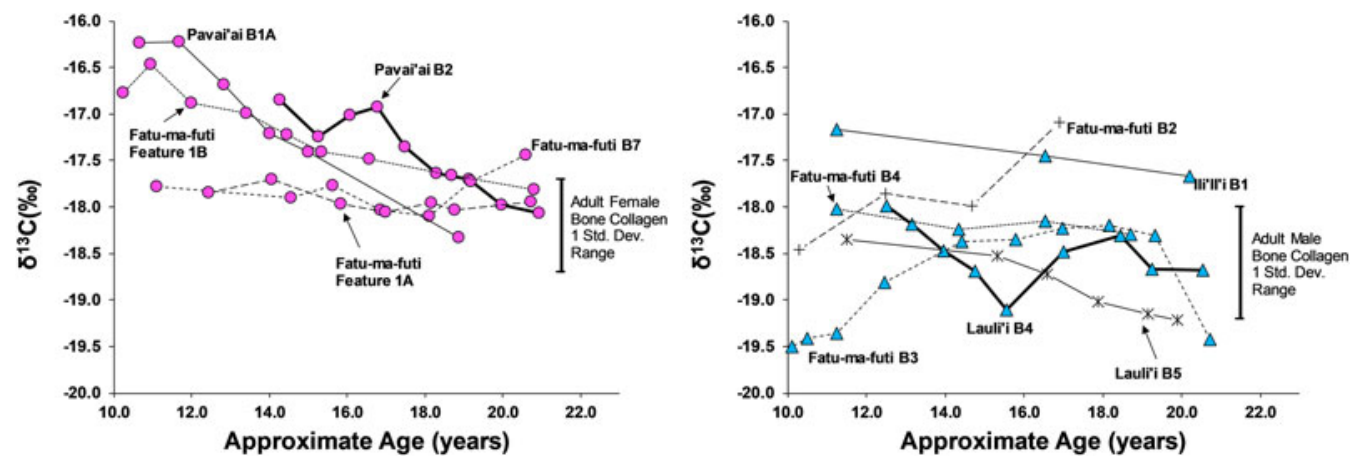

Figure 5. $\delta^{13} \mathrm{C}$ in serial sections of third molars from American Samoa for females (left) and males (right), with one standard deviation range for adult male and female bone collagen. 
sections, we estimate the weaning age at 1.4, 4.0, and 4.4 years for these three individuals. Although the sample size is small, these figures are somewhat later than the average weaning age of one-two years reported in studies in the mid-twentieth century (Bindon 1984, 1986; Gardner 1965:29; Nardi 1984). Instead, the reconstructed ages from archaeological samples are more in line with historical memory on the island, where weaning was typically after age two years (Malcolm 1954; Mead 1928). This suggests some discordance between breastfeeding behaviors in the last century with those earlier in time.

We did not sample enough first molars of individuals of known sex to determine whether the diets of young boys and girls less than 10 years of age were similar (as we had expected based on the ethnographic model). However, results from the study do suggest significant differences in the diets of early adolescent males and females. Thus, by age 10 years, there is a significant isotopic difference, where females are notably higher in $\delta^{13} \mathrm{C}$ and $\delta^{15} \mathrm{~N}$, suggesting a much greater role of marine foods in the diet of these juvenile girls. Further, the data show that the male-female difference in diet decreased throughout the second decade of life, but there was still a notable gap, even by age 20 years, where young women were still consuming greater amounts of marine food than men.
This archaeological pattern contrasts somewhat with historic and ethnographic accounts. Based on foraging behaviors and accounts of eating order within households, we had expected maturing boys (ca. ages 10-15) to be consuming greater amounts of marine food, similar to girls of that age. Instead, by age 10 most boys had transitioned to a diet lower in $\delta^{13} \mathrm{C}$ and $\delta^{15} \mathrm{~N}$, close to that of fully adult males, suggesting that they were already eating higher amounts of terrestrial food. Although there is interindividual variation in the diets of adolescent-aged males, this pattern was relatively stable through age 20 years (i.e., no noticeable shift with age for males between ages 10 and 20 years). If fishing and gleaning were an important part of the foraging behaviors of these maturing males, they do not seem to have been consuming a significant amount of the by-products of their labor.

Females, on the other hand, did show higher $\delta^{13} \mathrm{C}$ around age 10 years, as expected from the ethnographic model. However, throughout their second decade of life these maturing females decrease in $\delta^{13} \mathrm{C}$ and $\delta^{15} \mathrm{~N}$, suggesting a slow increase in terrestrial foods. By age 20 years, females are close to the bone collagen values of fully adult females for $\delta^{13} \mathrm{C}$ but still notably higher for $\delta^{15} \mathrm{~N}$. Based on the ethnographic model, where adult females continue to invest heavily in gleaning, we had expected adult

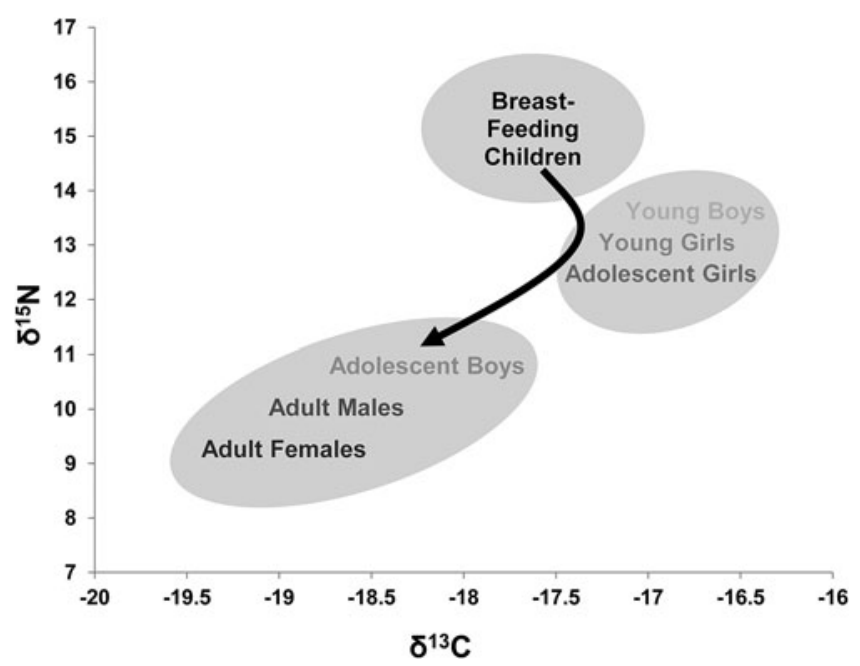

Figure 6. Generalized ontogenetic dietary profile for American Samoan males and females. 
females at age 20 years to remain above their male age cohort in $\delta^{13} \mathrm{C}$.

Together, the archaeological patterns suggest either that precontact activity patterns were different from ethnographic ones (i.e., boys and adult women did much less fishing in the past) or that harvested food and labor investment was discordant from actual diet and, hence, that there was widespread food sharing. There is much historical and ethnographic support for the latter. Detailed studies show significant redistribution of food within extended families or villages in the region (Bell 1931; Holmes 1957:312). This result also suggests that snacking explains very little of the age-sex variation in stable isotope results.

At the same time, we did document significant differences in the diets of young adolescent girls versus boys. This general pattern is shown in Figure 6. Thus, while life on Tutuila began and ended with similar dietary compositions, breast milk early in life and a terrestrial focus later in life, in between there was a marked difference in the role of marine versus terrestrial foods. Around age 10 this difference seems to have been greatest. If there was an age-sex bias in the order of food consumption within the household, and if marine foods were of lower status, this suggests that adolescent girls likely ate last and were of lowest status within the household. With age, the status gap decreased between males and females. Yet, even by 20 years of age, when many of the women were presumably starting their own families, there still existed a slight difference in diet by sex between individuals from the same age cohort.

\section{Conclusions}

We document a particular dietary life history for ancient American Samoa society wherein individuals transition from breast milk to greater incorporation of marine-derived foods and to consumption of more terrestrial-derived foods. This dietary life history seems to be accelerated for males relative to females. This finding contrasts slightly with ethnographically described labor life histories for individuals. Those studies suggest increased investment in fishing on the part of adolescent and young adult males and a lifelong focus on the gathering of sessile marine foods by females. Instead, the stable isotope data show less consumption of marine foods among adolescent and young adult males and fully adult females. In other words, assuming there is a direct correlation between diet and labor, the precontact diet does not seem to follow precisely the historic descriptions of sex- and age-based labor practices.

This result could represent, in part, a bias on the part of the ethnographic studies we consulted, which were, largely by design, focused on fishing and the exploitation of marine environments, rather than gardening and animal husbandry. On the other hand, the result may also reflect a key dynamic of precontact Samoan social organization, namely, the pooling and redistribution of foods within households. We expect discordance between labor efforts and diet when individuals specialize in exploiting particular environments for foods but give up and redistribute the fruits of their labor within sharing or exchange networks. In other words, the diet of individuals does not correlate directly with their daily subsistence activities when there is significant food sharing. As discussed above, ethnographic descriptions of day-to-day meals on American Samoa support such a redistributive system, with different foods tied to rank and feeding order within a household, rather than day-to-day subsistence activities.

Along these lines, because social status within the household was typically marked by greater access to certain foods (e.g., especially terrestrial-based foods such as pig), and these higherstatus terrestrial foods contrast isotopically with lower-status marine foods, serial samples in teeth may provide insight into the ages at which males and/or females transitioned in their social rank within households. In particular, shifts from less negative (i.e., higher) to more negative (i.e., lower) $\delta^{13} \mathrm{C}$ values on Tutuila may signal a change in social status and an earlier eating order position within the household. Likewise, differences between males and females in the ontogenetic timing of such shifts may reflect sexbiased access to social status and may be a means to reconstruct patriarchal or matriarchal social organizations in ancient societies.

Given the multitude of factors that play into the isotopic composition of diet (i.e., residence 
shifts, changing environment, etc.), it will always be important to contextualize serial samples within sites and to particular individuals. That is, we do not believe that serial samples, by themselves, will directly indicate social status or changes therein. Rather, combined with other contextual information from burials, such data might help delineate life history transitions for particular individuals.

In summary, rather than them being static, we record significant intra-individual variation in the isotopic composition of paleodiets in permanent first and third molars from American Samoa. Analysis shows that age and sex explain a large proportion of this isotopic variation. We interpret these findings within the context of life history processes, especially weaning and social status, that affected access to different foods for individuals. While the overall life history trajectory is similar, from breastfeeding, to a diet higher in marine foods, to a diet focused on terrestrial foods, the male life history appears to be accelerated relative to that of females. This finding may indicate earlier access to higher social status rungs for males.

Acknowledgments. We thank Dr. Pat Barker for discussions regarding ethnographic dietary patterns in American Samoa and his insights regarding status and eating order. We also thank Alex Greenwald for assistance in preparing teeth samples for analysis; Joy Matthew of the University of California, Davis, Stable Isotope Facility for help in analyzing collagen samples; and the American Samoa Power Authority for its support of this research. We thank Edgar Huerta for providing the Spanish abstract. Finally, we thank the peer reviewers and editor for their suggestions, which have greatly improved this article.

Data Availability Statement. All original data for this study are presented in Tables 1-2 within the body of the article.

\section{References Cited}

Addison, David J., and Tautala S. Asaua

2006 One Hundred New Dates from Tutuila and Manu'a: Additional Data Addressing Chronological Issues in Samoan Prehistory. Journal of Sämoan Studies 2:95-117.

Addison, David J., Tuipuavai Tago, Jeffery Toloa, and Erik Pearthree

2006 Ceramic Deposit below Fifth to Sixth Century AD Volcanic Ash Fall at Pava'ia'i, Tutuila Island, American Samoa: Preliminary Results from Site AS-31-171. New Zealand Journal of Archaeology 27:5-18.

Addison, David J., Greg Walter, and Alex E. Morrison 2008 The Initial Investigation of Fatu-ma-futi: An Ancient
Coastal Village Site, Tutuila Island, Territory of American Samoa. New Zealand Journal of Archaeology 29 (2007):89-107.

Ambrose, Stanley H., and Lynette C. Norr

1993 Experimental Evidence for the Relationship of the Carbon Isotope Ratios of Whole Diet and Dietary Protein to Those of Bone Collagen and Carbonate. In Prehistoric Human Bone. Archaeology at the Molecular Level, edited by Joseph B. Lambert and Guisela Grupe, pp. 1-37. Springer-Verlag, Berlin.

Bartelink, Eric J., and Phillip R. Johnson

2014 Bioarchaeological Analysis of Human Skeletal Remains from Tutuila Island, American Samoa. January 9. Report prepared for the American Samoa Historic Preservation Office, Pago Pago.

Beaumont, Julia, Andy Gledhill, Julia Lee-Thorp, and Janet Montgomery

2012 Childhood Diet: A Closer Examination of the Evidence from Dental Tissues Using Stable Isotope Analysis of Incremental Human Dentine. Archaeometry 55:277-295.

Beaumont, Julia, Janet Montgomery, Jo Buckberry, and Mandy Jay

2015 Infant Mortality and Isotopic Complexity: New Approaches to Stress, Maternal Health, and Weaning. American Journal of Physical Anthropology 157:441457.

Bell, F. L. S.

1931 The Place of Food in the Social Life of Central Polynesia. Oceania 2:117-135.

Bindon, James R.

1984 A Nutritional Evaluation of the Diet of Three Groups of Samoan Adults: Modernization and Dietary Adequacy. Ecology of Food and Nutrition 14:105-115.

1986 Dietary Patterns of Children in American Samoa: Multivariate Analysis of Food Groups and Household Associations. Ecology of Food and Nutrition 18:331338.

1988 Taro or Rice, Plantation or Market: Dietary Choice in American Samoa. Food and Foodways 3:59-78.

Burt, Nicole M.

2015 Individual Dietary Patterns during Childhood: An Archaeological Application of a Stable Isotope Microsampling Method for Tooth Dentin. Journal of Archaeological Science 53:277-290.

Casu, Daniela, Giulia Ceccherelli, Nicola Sechi, Paola Rumolo, and Gianluca Sara

2009 Caulerpa racemosa var. cylindracea as a Potential Source of Organic Matter for Benthic Consumers: Evidences from a Stable Isotope Analysis. Aquatic Ecology 43:1023-1029.

Cerling, Thure E., James R. Ehleringer, and John M. Harris 1998 Carbon Dioxide Starvation, the Development of $\mathrm{C}_{4}$ Ecosystems and Mammalian Evolution. Proceedings of the Royal Society of London B 353:159-171.

Cochrane, Ethan E., Timothy M. Rieth, and William R. Dickinson

2013 Plainware Ceramics from Sāmoa: Insights into Ceramic Chronology, Cultural Transmission, and Selection among Colonizing Populations. Journal of Anthropological Archaeology 32:499-510.

Commendador, Amy S., John V. Dudgeon, Bruce P. Finney, Benjamin T. Fuller, and Kelley S. Esh

2013 A Stable Isotope $\left(\delta^{13} \mathrm{C}\right.$ and $\left.\delta^{15} \mathrm{~N}\right)$ Perspective on Human Diet on Rapa Nui (Easter Island) ca. AD 
1400-1900. American Journal of Physical Anthropology 152:173-185.

Crittenden, Alyssa N., and Courtney L. Meehan

2016 Multiple Perspectives on the Evolution of Childhood. In Childhood: Origins, Evolution, and Implications, edited by Courtney L. Meehan and Alyssa N. Crittenden, pp. 1-8. School of Advanced Research, Albuquerque, New Mexico.

Davidson, Janet M.

1969 Settlement Patterns in Samoa before 1840. Journal of the Polynesian Society 78:44-82.

Eckert, Suzanne L., and Daniel R. Welch

2013 A Commanding View of the Pacific: Highland Land Use as Viewed from Vainu'u, a Multi-component Site on Tutuila Island, American Samoa. Archaeology in Oceania 48:13-25.

Eerkens, Jelmer W., and Eric J. Bartelink

2013 Sex-Biased Weaning and Early Childhood Diet among Middle Holocene Hunter-Gatherers in Central California. American Journal of Physical Anthropology 152:471-483.

Eerkens, Jelmer W., Ada G. Berget, and Eric J. Bartelink

2011 Estimating Weaning and Early Childhood Diet from Serial Micro-samples of Dentin Collagen. Journal of Archaeological Science 38:3101-3111.

Eerkens, Jelmer W., Madeline Mackie, and Eric J. Bartelink 2013 Brackish Water Foraging and Isotopic Landscapes in Central California: Dietary Reconstruction in a Late Holocene Hunter-Gatherer Population in Suisun Marsh. Journal of Archaeological Science 40:3270-3281.

Eerkens, Jelmer W., Kelli Sullivan, and Alexandra M. Greenwald

2016 Stable Isotope Analysis of Serial Samples of Third Molars as Insight into Inter- and Intra-individual Variation in Ancient Diet. Journal of Archaeological Science: Reports 5:656-663.

Ehleringer, James R., Rowan F. Sage, Lawrence B. Flanagan, Robert W. Pearcy

1991 Climate Change and the Evolution of $\mathrm{C}_{4}$ Photosynthesis. Trends in Ecology and Evolution 6:95-99.

Ember, Melvin

1962 Political Authority and the Structure of Kinship in Aboriginal Samoa. American Anthropologist 64:964-971.

Farquhar, Graham D., James R. Ehleringer, and Kerry T. Hubick

1989 Carbon Isotope Discrimination and Photosynthesis. Annual Review of Plant Physiology and Plant Molecular Biology 40:503-537.

Fernandes, Rircardo, Marie-Josée Nadeau, and Pieter M. Grootes

2012 Macronutrient-Based Model for Dietary Carbon Routing in Bone Collagen and Bioapatite. Archaeological and Anthropological Sciences 4:291-301.

Fuller, Benjamin T., Michael P. Richards, and S. Mays

2003 Stable Carbon and Nitrogen Isotope Variations in Tooth Dentine Serial Sections from Wharram Percy. Journal of Archaeological Science 30:1673-1684.

Gardner, Louise C.

1965 Gautavai: A Study of Samoan Values. Unpublished Master's thesis, Department of Anthropology, University of Hawaii, Honolulu.

Hill, Harry B.

1978 The Use of Near Shore Marine Life as a Food Resource by American Samoans. Miscellaneous Work Papers 1. Pacific Islands Studies Program, University of Hawaii, Honolulu.
Hill, Kim Ronald, and A. Magdalena Hurtado

1996 Ache Life History: The Ecology and Demography of a Foraging People. Aldine, New York.

Hillson, Simon

1996 Dental Anthropology. Cambridge University Press, Cambridge.

2014 Tooth Development in Human Evolution and Bioarchaeology. Cambridge University Press, Cambridge.

Holmes, Lowell D.

1957 Ta'u: Stability and Change in a Samoan Village. Journal of the Polynesian Society 66:301-338.

1974 Samoan Village. Holt, Rinehart and Winston, New York.

Jarman, Catrine L., Thomas Larsen, Terry Hunt, Carl Lipo, Reidar Solsvik, Natalie Wallsgrove, Cassie Ka'apuLyons, Hilary G. Close, and Brian N. Pop

2017 Diet of the Prehistoric Population of Rapa Nui (Easter Island, Chile) Shows Environmental Adaptation and Resilience. American Journal of Physical Anthropology 164:343-361.

Kailihiwa, Solomon H., Juanita A. Beck, and Paul L. Cleghorn

2005 Data Recovery Fatumafuti Village, Tutuila Island, American Samoa. Report on file at the American Samoa Historic Preservation Office, Pago Pago.

Kellner, Corina M., and Margaret J. Schoeninger

2007 A Simple Carbon Model for Reconstructing Prehistoric Human Diet. American Journal of Physical Anthropology 133:1112-1127.

Kinaston, Rebecca L., Stuart Bedford, Michael Richards, Stuart Hawkins, Andrew Gray, Klervia Jaouen, Frederique Valentin, and Hallie Buckley

2014 Diet and Human Mobility from the Lapita to the Early Historic Period on Uripiv Island, Northeast Malakula, Vanuatu. PLoS ONE 9(8): e104071.

Kinaston, Rebecca L., Hallie R. Buckley, and Andrew Gray 2013 Diet and Social Status on Taumako, a Polynesian Outlier in the Southeastern Solomon Islands. American Journal of Physical Anthropology 151:589603.

Krämer, Augustin F.

1994 The Samoa Islands. An Outline of a Monograph with Particular Consideration of German Samoa, Vol. 1: Constitution, Pedigrees and Traditions. Translated by Theodore E. Verhaaren (1978). University of Hawai'i Press, Honolulu. Originally published 1902, Die Samoa-Inseln, E. Naegele, Stuttgart, Germany.

Ladio, Ana H., and Mariana Lozada

2001 Nontimber Forest Product Use in Two Human Populations from Northwest Patagonia: A Quantitative Approach. Human Ecology 29:367-380.

Leach, B. Foss, Christopher J. Quinn, and G. L. Lyon

1996 A Stochastic Approach to the Reconstruction of Prehistoric Human Diet in the Pacific Region from Bone Isotope Signatures. Tuhinga 8:1-54.

Longin, Robert

1971 New Method of Collagen Extraction for Radiocarbon Dating. Nature 230(5291):241-242.

Lupo, Karen D.

2006 What Explains the Carcass Field Processing and Transport Decisions of Contemporary HunterGatherers? Measures of Economic Anatomy and Zooarchaeological Skeletal Part Representation. Journal of Archaeological Method and Theory 13:19-66.

Malcolm, Sheila $\mathrm{H}$.

1954 Diet and Nutrition in American Samoa. South 
Pacific Commission Technical Paper No. 63. South Pacific Commission, Nouméa, New Caledonia.

Mead, Margaret

1928 Coming of Age in Samoa. Morrow, New York.

Minagawa, Masao, and Eitaro Wada

1984 Stepwise Enrichment of ${ }^{15} \mathrm{~N}$ along Food Chains:

Further Evidence and the Relation between $\delta^{15} \mathrm{~N}$ and

Animal Age. Geochimica et Cosmochimica Acta 48:1135-1140.

Morrison, Alex E., and David J. Addison

2008 Assessing the Role of Climate Change and Human Predation on Marine Resources at the Fatu-ma-futi site, Tutuila Island, American Samoa: An Agent Based Model. Archaeology in Oceania 43:22-34.

2009 Examining Causes and Trends in Marine Trophic Level Change: 1500 Years of Fish Exploitation at Fatu-ma-futi, Tutuila Island, American Sāmoa. Journal of Island and Coastal Archaeology 4:177-194.

Nagaoka, Lisa

1993 Faunal Assemblages from the To'aga Site. In The To'aga Site: Three Millennia of Polynesian Occupation in the Manu'a Islands, American Samoa, edited by Patrick V. Kirch and Terry L. Hunt, pp. 189-216. Contributions of the University of California Archaeological Research Facility 51. UC Berkeley, Berkeley, CA.

Nardi, Bonnie A.

1984 Infant Feeding and Women's Work in Western Samoa: A Hypothesis, Some Evidence and Suggestions for Future Research. Ecology of Food and Nutrition 14:277-286.

O'Connell, T. C., C. J. Kneale, N. Tasevska, and G. G. C. Kuhnle

2012 The Diet-Body Offset in Human Nitrogen Isotopic Values: A Controlled Dietary Study. American Journal of Physical Anthropology 149:426-434.

Ogden, Cynthia L., Brian K. Kit, Margaret D. Carroll, and Sohyun Park

2011 Consumption of Sugar Drinks in the United States, 2005-2008. National Center for Health Statistics Data Brief 71:1-8.

Quinlan, Robert J.

2007 Human Parental Effort and Environmental Risk. Proceedings of the Royal Society B 274:121-125.

Quintus, Seth, and Ethan E. Cochrane

2017 Pre-contact Samoan Cultivation Practices in Regional and Theoretical Perspective. Journal of Island and Coastal Archaeology. https://doi.org/10.1080/15564894.2017. 1285835, accessed July 2018.

Rieth, Timothy M., and David J. Addison

2008 How Dark Are They? The Sāmoan Dark Ages, 1500-1000 BP. In Recent Advances in the Archaeology of the Fiji/West-Polynesia Region, edited by David J. Addison and Christophe Sand, pp. 87-96. University of Otago Press, Dunedin, New Zealand.

Rieth, Timothy M., and Terry L. Hunt

2008 A Radiocarbon Chronology for Sāmoan Prehistory. Journal of Archaeological Science 35:1901-1927.

Rieth, Timothy M., Alex E. Morrison, and David J. Addison 2008 The Temporal and Spatial Patterning of the Initial
Settlement of Sāmoa. Journal of Island and Coastal Archaeology 3:214-239.

Schoeninger, Margaret J.

1985 Trophic Effects on ${ }^{15} \mathrm{~N} /{ }^{14} \mathrm{~N}$ and ${ }^{13} \mathrm{C} /{ }^{12} \mathrm{C}$ Ratios in Human Bone Collagen and Strontium Levels in Bone Mineral. Journal of Human Evolution 14:515-525.

Schoeninger, Margaret J., Michael J. DeNiro, and Henrik Tauber

1983 Stable Nitrogen Isotope Ratios of Bone Collagen Reflect Marine and Terrestrial Components of Prehistoric Human Diet. Science 220:1381-1383.

Stantis, Christina, Hallie R. Buckley, Rebecca L. Kinaston, Patrick D. Nunn, Klervia Jaouen, and Michael P. Richards

2016 Isotopic Evidence of Human Mobility and Diet in a Prehistoric/Protohistoric Fijian Coastal Environment (c. 750-150 BP). American Journal of Physical Anthropology 159:478-495.

Stearman, Allyn MacLean

1991 Making a Living in the Tropical Forest: Yuqui Foragers in the Bolivian Amazon. Human Ecology 19:245-260.

Tcherkézoff, Serge

2000 The Samoan Category Matai (“Chief”): A Singularity in Polynesia? Historical and Etymological Comparative Queries. Journal of the Polynesian Society 109:151-190.

Tieszen, Larry L., and Tim Fagre

1993 Effect of Diet Quality and Composition on the Isotopic Composition of Respiratory CO2, Bone Collagen, Bioapatite, and Soft Tissues. In Prehistoric Human Bone: Archaeology at the Molecular Level, edited by Joseph B. Lambert and Guisela Grupe, pp. 121-155. Springer-Verlag, Berlin.

Trivers, Robert L.

1974 Parent-Offspring Conflict. American Zoologist 14:249-264.

Valentin, Frédérique, Hallie R. Buckley, Estelle Herrscher, Rebecca Kinaston, Stuart Bedford, Matthew Spriggs, Stuart Hawkins, and Ken Neal

2010 Lapita Subsistence Strategies and Food Consumption Patterns in the Community of Teouma (Efate, Vanuatu). Journal of Archaeological Science 37:1820-1829.

Valentin, Frédérique, Estelle Herrscher, Fiona Petchey, and David J. Addison

2011 An Analysis of the Last 1000 Years Human Diet on Tutuila (American Samoa) Using Carbon and Nitrogen Stable Isotope Data. American Antiquity 76:473-486.

Wang, Y. Claire, Sara N. Bleich, and Steven L. Gortmaker 2008 Increasing Caloric Contribution from SugarSweetened Beverages and 100\% Fruit Juices among US Children and Adolescents, 1988-2004. Pediatrics 121(6):e1604-e1614.

Submitted December 22, 2017; Revised October 26, 2018; Accepted October 27, 2018 